\title{
WoSIS: providing standardised soil profile data for the world
}

\author{
Niels H. Batjes, Eloi Ribeiro, Ad van Oostrum, Johan Leenaars, Tom Hengl, and Jorge Mendes de Jesus \\ ISRIC - World Soil Information, Wageningen, 6708 PB, the Netherlands \\ Correspondence to: Niels H. Batjes (niels.batjes@isric.org)
}

Received: 22 July 2016 - Published in Earth Syst. Sci. Data Discuss.: 21 October 2016

Revised: 19 December 2016 - Accepted: 22 December 2016 - Published: 17 January 2017

\begin{abstract}
The aim of the World Soil Information Service (WoSIS) is to serve quality-assessed, georeferenced soil data (point, polygon, and grid) to the international community upon their standardisation and harmonisation. So far, the focus has been on developing procedures for legacy point data with special attention to the selection of soil analytical and physical properties considered in the GlobalSoilMap specifications (e.g. organic carbon, soil $\mathrm{pH}$, soil texture (sand, silt, and clay), coarse fragments $(<2 \mathrm{~mm}$ ), cation exchange capacity, electrical conductivity, bulk density, and water holding capacity). Profile data managed in WoSIS were contributed by a wide range of soil data providers; the data have been described, sampled, and analysed according to methods and standards in use in the originating countries. Hence, special attention was paid to measures for soil data quality and the standardisation of soil property definitions, soil property values, and soil analytical method descriptions. At the time of writing, the full WoSIS database contained some 118400 unique "shared" soil profiles, of which some 96000 are georeferenced within defined limits. In total, this corresponds with over 31 million soil records, of which some $20 \%$ have so far been quality-assessed and standardised using the sequential procedure discussed in this paper. The number of measured data for each property varies between profiles and with depth, generally depending on the purpose of the initial studies. Overall, the data lineage strongly determined which data could be standardised with acceptable confidence in accord with WoSIS procedures, corresponding to over 4 million records for 94441 profiles. The publicly available data - WoSIS snapshot of July 2016 - are persistently accessible from ISRIC WDC-Soils through doi:10.17027/isric-wdcsoils.20160003.
\end{abstract}

\section{Introduction}

Soil is an important provider of ecosystem services (UNEP, 2012; MEA, 2005). Yet this natural resource, considered to be non-renewable on a human life span, is being threatened (FAO and ITPS, 2015; UNEP, 2014). Worldwide, professionals, scientists, "decision makers and managers must have access to the information they need, when they need it, and in a format they can use" (GEO, 2010). Large numbers of consistent soil profile data of known provenance (lineage) are needed to accurately model and map the status of the world's soil resources at increasingly detailed resolutions (Omuto et al., 2012; Hengl et al., 2014; Arrouays et al., 2014; FAO and ITPS, 2015).

This paper describes procedures for safeguarding, standardising/harmonising, and subsequently serving of consis- tent world soil data to the international community as developed in the framework of the WoSIS (World Soil Information Service) project. In essence, the development of the WoSIS server database may be seen as a sequel to earlier collaborative, but still "stand-alone", compilations of soil legacy data coordinated by ISRIC such as WISE (Batjes, 2009), SOTER (van Engelen and Dijkshoorn, 2013), and the Africa Soil Profiles database (Leenaars, 2013). Ultimately, WoSIS aims to serve consistent harmonised soil data (point, polygon and grids), derived both from a wide range of shared legacy holdings and from recently developed soil spectral libraries (e.g. Viscarra Rossel et al., 2016; Shepherd and Walsh, 2002), in an interoperable mode and this preferably in the setting of a federated global soil information system. 
Harmonisation, as defined by the Global Soil Partnership (GSP; Baritz et al., 2014), involves "providing mechanisms for the collation, analysis and exchange of consistent and comparable global soil data and information". Areas of harmonisation include those related to (a) soil description, classification and mapping, (b) soil analyses, (c) exchange of digital soil data, and (d) interpretations. So far, considering the breadth and magnitude of the task, the focus in WoSIS has been on the standardisation of soil property definitions, soil analytical method descriptions, and soil property values for those properties considered in the GlobalSoilMap specifications (GlobalSoilMap, 2013). Such a standardisation is a prerequisite for the development/testing of a soil information model that can underpin global soil data interoperability and modelling (Omuto et al., 2012). Quality-assessed profile data served from WoSIS, and its predecessors as discussed above, may be used for various purposes such as conventional respectively digital mapping of soil properties and soil classes (Batjes, 2016; Hengl et al., 2015, 2016). In turn, such derived products may be used in studies that address a range of global issues at various scale levels (e.g. Hendriks et al., 2016; Luo et al., 2016; Jones and Thornton, 2015; Maire et al., 2015).

\section{Data and methods}

\subsection{Basic principles}

Everyone may contribute data for inclusion in WoSIS. Data may be submitted in various ways. Analogue data should be provided using a template with standardised variable names as described in the WoSIS Procedures Manual (Ribeiro et al., 2015, pp. 378-40). Alternatively, large digital datasets comprising over a thousand profiles can be provided to ISRIC as zip files containing the database, documentation, and metadata. Prior to any data processing at ISRIC the data provider must agree in writing with the terms of the data policy (ISRIC, 2016). The access rights and data provenance (lineage), as documented in the metadata, will determine which quality-assessed data may later be served freely to the international community. Therefore, when processing the wealth of contributed data, priority is given to those datasets that have a "non-restrictive" Creative Commons licence, defined here as at least a CC BY (Attribution) or CC BY-NC (Attribution Non-Commercial). The corresponding source data will be gradually standardised and harmonised to make them "comparable as if assessed by a given (reference) method" (Fig. 1). Ultimately, only the quality-assessed and standardised/harmonised "shared" data will be served to the international community.

\subsection{Measures for data quality}

As indicated, soil profile data submitted for consideration in WoSIS were collated according to various national or international standards. Therefore, proper documentation, in so

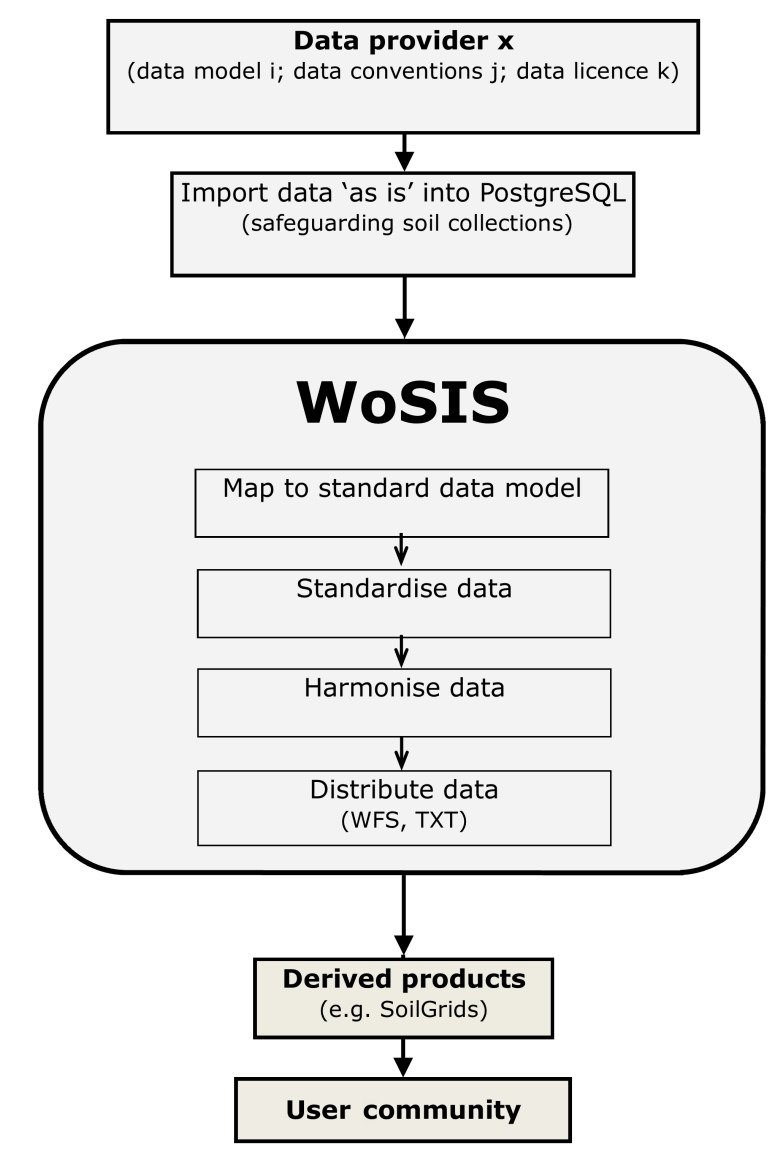

Figure 1. General procedure for processing data in WoSIS.

far as possible, of the provenance and identification of each dataset, and ideally each observation or measurement, is essential to allow for efficient processing of the data; such aspects are discussed later in detail.

For soil observations and measurements, the following need to be specified: feature $(x-y-z$ and time $(t)$ referenced profiles and layers), attribute (class, site, layer-field, and layer-lab), method, and value, including units of expression (Leenaars, 2013; Leenaars et al., 2014; Ribeiro et al., 2015). As indicated by Chapman (2005), "too often, data are used uncritically without consideration of the error contained within, and this can lead to erroneous results, misleading information, unwise environmental decisions and increased costs". WoSIS is being populated using data produced for different types of studies ranging from routine soil surveys to more specific assessments, each of these having their specific quality requirements (Landon, 1991; Soil Survey Division Staff, 1993). The corresponding samples were analysed in a range of laboratories or in the field according to a wide range of methods (e.g. wet chemistry or soil spectroscopy), each with their own uncertainty and costs. As indicated by Kroll (2008), issues of soil data quality are not restricted to 
uncertainty issues; they also include aspects like completeness, accessibility, and verifiability (traceability) of data.

A review of quality aspects specifically related to soil data led to consideration of three quality indicators in WoSIS: (a) observation date (date of observation or measurement), (b) level of trust (a subjective measure inferred from soil expert knowledge), and (c) accuracy (an indicator for the laboratory and field-related uncertainty as well as the accuracy of georeferencing). These indicators provide measures that allow the WoSIS database manager to recognise factors that may compromise the quality of certain data and hence their suitability for use. Consideration of such quality indicators ensures that objective methods are applied for evaluating data in the database, while at the same time the system enables soil expert knowledge to override these assessments when needed. In practice, however, the information provided with some source materials does not allow for a full characterisation of all three indicators. In particular, the accuracy of individual analytical measurements is seldom expressed in the source databases as such information is generally maintained in separate soil laboratory information systems (see van Reeuwijk, 1998; WEPAL, 2015) to which we have no access. Alternatively, a measure for the positional accuracy is provided for each profile (e.g. "0.01" when degrees, minutes, and seconds are provided; see Ribeiro et al., 2015, p. 90).

\subsection{Standard data model}

Sometimes, the source data may be in paper (analogue) format in which case they must first be digitised following certain basic criteria (Ribeiro et al., 2015, pp. 37-40; Leenaars et al., 2014, p. 52). Preferably, data entry is done by the data providers, as they best know their data. Basically, this first step amounts to "safeguarding soil data collections" at risk of being lost. This is an important remit of ISRIC as World Data Centre for Soils (WDC-Soils) of the ICSU World Data System.

Any submitted digital dataset is first assessed as regards its overall suitability for inclusion in WoSIS (e.g. licence and metadata). After this filtering, the data are imported "as is" into PostgreSQL, an open-source database management system. At this early stage of processing, the data are still organised according to numerous data models, data conventions and data contents. Therefore, the next step (yet first step of standardisation) is to map these disparate data to the WoSIS standard data model (Fig. 1); technical details are provided elsewhere (Ribeiro et al., 2015).

\subsection{Identifying repeated profiles}

Being derived from multiple data sources, some of which are compilations, there is a risk that the same profiles are imported several times into WoSIS, albeit using different identifiers. Computerised procedures that consider lineage and geographical proximity checks were developed to screen for

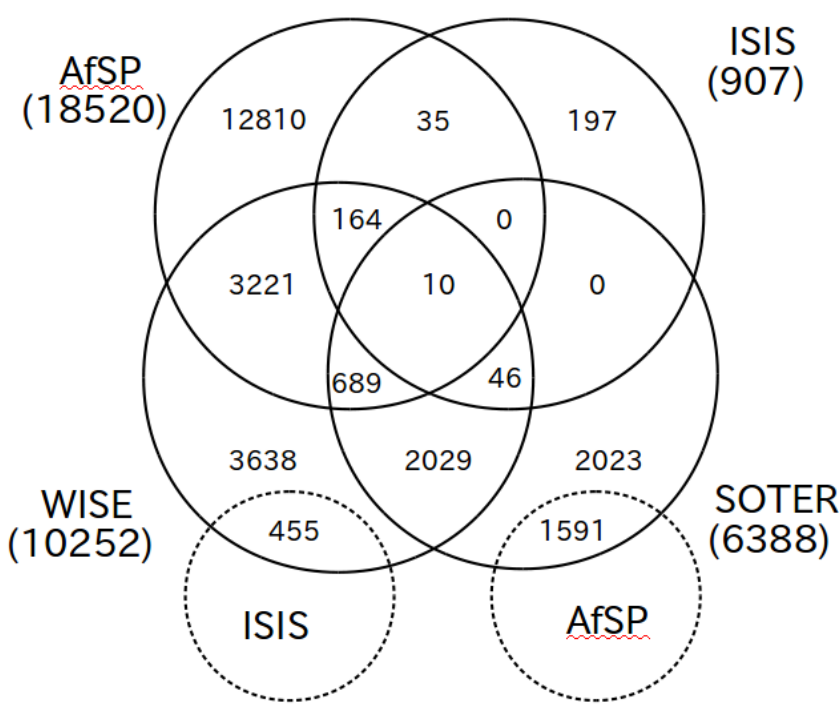

Figure 2. Flagging of repeated profiles between the AfSP, ISIS, WISE, and SOTER databases (see text for explanation of abbreviations).

possible repeated profiles. The lineage check considers the data source identifiers, uses this information to trace the original data source, and from there looks for duplicates. Alternatively, the proximity check is based on the geographic coordinates. It first identifies profiles that are suspiciously close to another (e.g. $<10 \mathrm{~m}$ ). Subsequently, the information for these profiles is compared and the database manager assesses the likelihood of such profiles being identical (Ribeiro et al., 2015, pp. 5-6). Figure 2 serves to show the results of this time-consuming process for four databases: ISIS (2015), the ISRIC Soil Information System (reference collection); WISE, World Inventory of Soil Emission potentials (compilation; Batjes, 2009); SOTER, Soil and Terrain databases (compilation; Van Engelen, 2011); and AfSP, the Africa Soil Profiles database (compilation; Leenaars, 2013). For example, 12810 profiles are present only in AfSP; 35 are shared among AfSP and ISIS (the original source); 164 are shared between AfSP, WISE, and ISIS; and 10 profiles occur in the four databases. In the case of duplicate profiles, all the corresponding data will nonetheless be standardised as described below (i.e. the "flagged" data are maintained in the WoSIS database). However, ultimately, only the profile with the most complete data and detailed lineage will be distributed (see Sect. 3).

\subsection{Basic data quality assessment and control}

All data sources are submitted to the same QA/QC checks, building on procedures developed for the WISE (Batjes, 1995, pp. 52-53) and AfSP (Leenaars, 2013, pp. 125-128) database. For example, this includes checks on referential integrity, data types, geolocation, units of expression, domain 
ranges, as well as possible "latitude-longitude inversions" in profile coordinates. It is assumed that the quality requirements of the data provider are met and that basic quality checks and screening have taken place, and this with due consideration for any soil-specific options in the laboratory procedures (Ribeiro et al., 2015). This approach allows users of WoSIS-derived datasets to make their own judgement on the quality of individual analytical data, for instance by the assumption that selected data have comparable quality characteristics or an acceptable (inferred) quality compared to their requirements.

\subsection{Standardisation of soil analytical method descriptions}

As indicated, there is often no detailed quantitative information on the quality and uniformity of the soil analytical data held in the diverse source databases. Full quality control, including verification of in-profile consistencies, requires the data to be harmonised according to an analytical reference method. The foreseen ultimate step of data harmonisation, converting property values assessed with analytical method $X$ to values "as if" assessed by reference method $Y$, requires an unambiguous identification and definition of the various analytical methods. Therefore, it was first necessary to develop a qualitative procedure to describe the analytical methods, including their method features, in a flexible yet comprehensive and consistent way.

The options selected for the analytical method features in WoSIS are assigned on basis of the descriptions in the respective (database) sources. This implies that information, as interpreted or distilled from the original report (source materials) by the data compilers, was used in WoSIS. In the future, some refinements may still prove possible or necessary should the original materials, such as laboratory manuals, be consulted again. In essence, the WoSIS approach for the qualitative description of soil analytical methods can be seen as complementary to method descriptions used in reports from proficiency tests (NATP, 2015; van Reeuwijk, 1998; WEPAL, 2015). In such tests, results from participants are coded to provide details of the methods applied for a particular grouping (e.g. CEC, cation exchange capacity). As discussed in Ribeiro et al. (2015), the spread of these results may give an indication of the maximum spread in a compiled database.

In addition to the method description according to the standardised coding system developed for WoSIS, measures have been allocated for the inferred confidence in each "method conversion" (i.e. from low to high); of necessity, this qualitative assessment is based solely on the information embedded in the "summarised" method descriptions as provided in the various source databases. As indicated, such descriptions have often been generalised from a more detailed source, such as a laboratory manual. Importantly, the provided con- fidence flags should not be seen as a measure for the quality of a particular laboratory.

\subsection{Towards the harmonisation of world soil data}

Depending on the projected applications, user communities will require specific sets of data. As indicated, in the first version, we limited ourselves to the list of properties considered in the GlobalSoilMap specifications (GlobalSoilMap, 2013): soil pH, soil organic carbon content, effective cation exchange capacity, electrical conductivity, soil texture (sand, silt, and clay content), proportion of fragments $>2 \mathrm{~mm}$, bulk density, and water retention. In the respective source databases, these properties were determined using a range of analytical procedures, thus requiring standardisation of the soil analytical method descriptions to make them "fit for use" and comparable (Leenaars et al., 2014). Key in the approach developed for WoSIS is that "a property is best described by key elements of the (laboratory) procedure applied" (Soil Survey Staff, 2011). Similarly, in WoSIS, major features of commonly used methods for determining a given soil property are characterised. For soil $\mathrm{pH}$, for example, these are the solution, concentration, ratio (soil/solution), and instrument. As indicated, the key component features can be aggregated where considered as being comparable in the context of global or regional level data analyses. For example, soil pH data measured in a $\mathrm{KCl}$ solution, $1 \mathrm{M}$, at a soil / liquid ratio of $1: 5$, and using a conventional electrode can be aggregated within the group considered to meet the ISO 10390:2005 criteria for $\mathrm{pH}-\mathrm{KCl}$ (ISO, 2015). Similarly, the combination $\mathrm{KCl}$ solution, $1 \mathrm{M}, 1: 2.5$ soil / liquid ratio, and a conventional electrode broadly corresponds to ISRIC criteria (van Reeuwijk, 2002). Similar principles were applied for all soil properties under consideration here as described in Ribeiro et al. (2015, pp. 47-53).

A next, desired step would be to make the data (e.g. pH, CEC, or organic carbon) comparable, "as if" assessed by a single given (reference) method. That is, fully "harmonised" and unambiguously defined. However, there is generally no universal equation for converting property values from one method to another in all situations (GlobalSoilMap, 2013; Jankauskas et al., 2006; Lettens et al., 2007). Basically, this implies that within the framework of the Global Soil Partnership (GSP), for example, each regional or continental node will need to develop and apply node-specific conversion functions (towards the yet to be defined GSP-adopted standard reference methods; see Baritz et al., 2014), building on comparative analyses using say archived soil samples and spectral libraries.

\section{Serving consistent standardised data}

The WoSIS server database itself provides an important building block for the spatial data infrastructure (Fig. 3) through which ISRIC WDC-Soils will be serving an increas- 


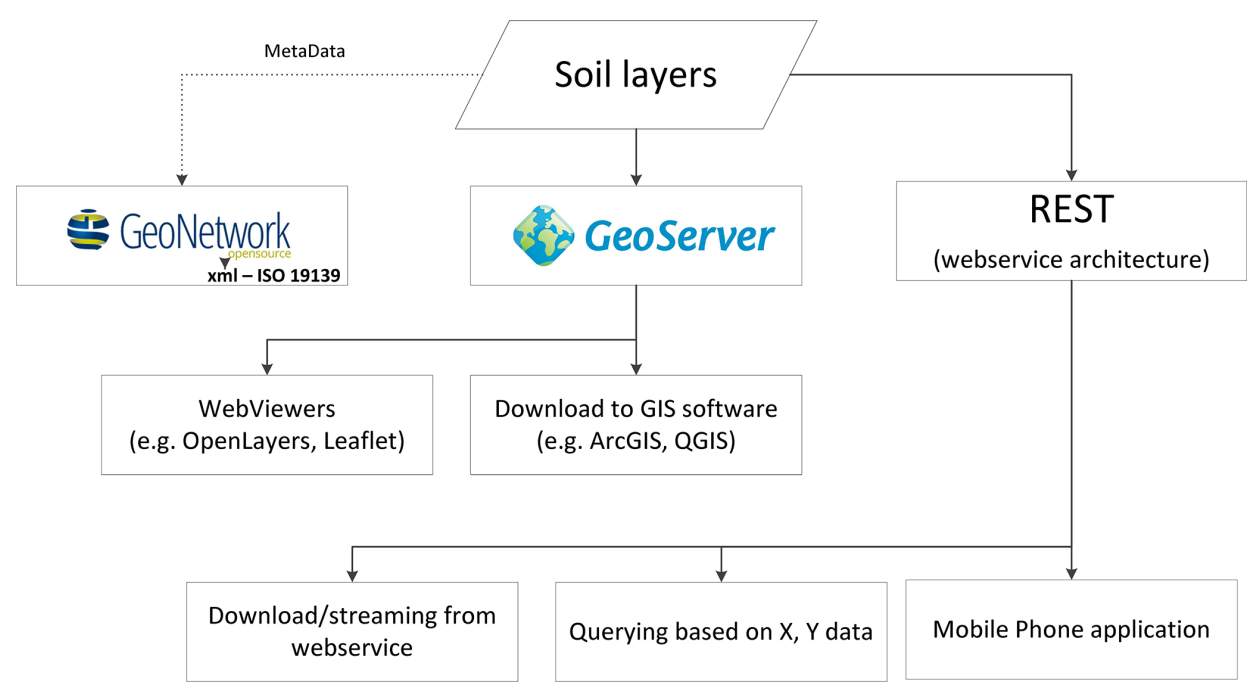

Figure 3. Serving consistent soil layers from WoSIS to the user community through ISRIC's evolving spatial data infrastructure.

ing range of data (point, raster and polygon) to the international community (Batjes et al., 2013; Hengl et al., 2016). The most recent set of WoSIS-derived point data is served "24/7" via an OGC-compliant WFS (Web Feature Service) provided by GeoServer instance. These data may be accessed freely via the following webpage: http://www.isric. org/content/wosis-distribution-set. By its nature, however, this dataset will be dynamic as it will grow when additional point data are processed, additional soil attributes are considered, and/or when possible corrections are required. Therefore, for consistent modelling and citation purposes, we provide static snapshots of the standardised data with clear time stamps, in tab-separated-values format. Each snapshot will have a unique name and digital object identifier (DOI), for example file WoSIS_2016_July.zip with doi:10.17027/isricwdcsoils.20160003.

At the time of writing, the WoSIS server database contained some 118400 unique "shared" soil profiles, out of which over 96000 are georeferenced within defined limits, corresponding with some 31 million soil records in total. So far, some $20 \%$ thereof have been quality-assessed and standardised using the sequential procedure discussed in this paper. As indicated, the number of measured data for each property varies between profiles and with depth, generally depending on the purpose of the initial studies. Therefore, the data lineage strongly determined which specific data could be served with acceptable confidence (as flagged in the central WoSIS database; see Ribeiro et al., 2015, p. 92). By implication, the "July 2016" snapshot only includes standardised data for 94441 geo-referenced profiles, representing some 455000 layers (or horizons). In total, this corresponds to over 4 million records that include both numeric (19, e.g. sand content or soil $\mathrm{pH}$ ) and class (3, e.g. WRB soil classification) properties. The naming conventions and units of mea- surement are described in Appendix A, and file structure is described in Appendix B.

The number of profiles per continent is highest for North America (63 077) and Africa (17153), followed by South America (8970), Asia (3089), Europe (1908), Oceania (235), and Antarctica (9). These profiles come from 148 countries; the average density of observations is 0.7 profiles per $1000 \mathrm{~km}^{2}$. The actual density of observations varies greatly, both between countries (Appendix C) and within each country (Fig. 4). Such geographic gaps will be filled gradually in the future, this largely depending though on the willingness or ability of data providers to freely share (some of) their data for consideration in WoSIS. Alternatively, it should be noted here that some recently shared datasets are not yet included in the present snapshot (e.g. Australia, Canada, and Cambodia).

\section{Towards global soil data interoperability}

So far, all datasets managed in WoSIS were provided as "stand-alone" databases; as such their content is "static". Steps are being made towards the development of a federated, and ultimately interoperable, service or spatial soil data infrastructure (SDI) through which source data are served and updated by the respective data providers and made queryable according to the agreed upon data standards. A first, possible step in this direction - though not yet interoperable - is the exchange of data using a foreign-data wrapper (FWD). Subsequently, the "transferred" data can be mapped to the WoSIS data model for further standardisation and harmonisation as described earlier. A technically more challenging solution for the worldwide exchange of soil data was implemented during the OGC Soil Data Interoperability Experiment (SoilIE). 


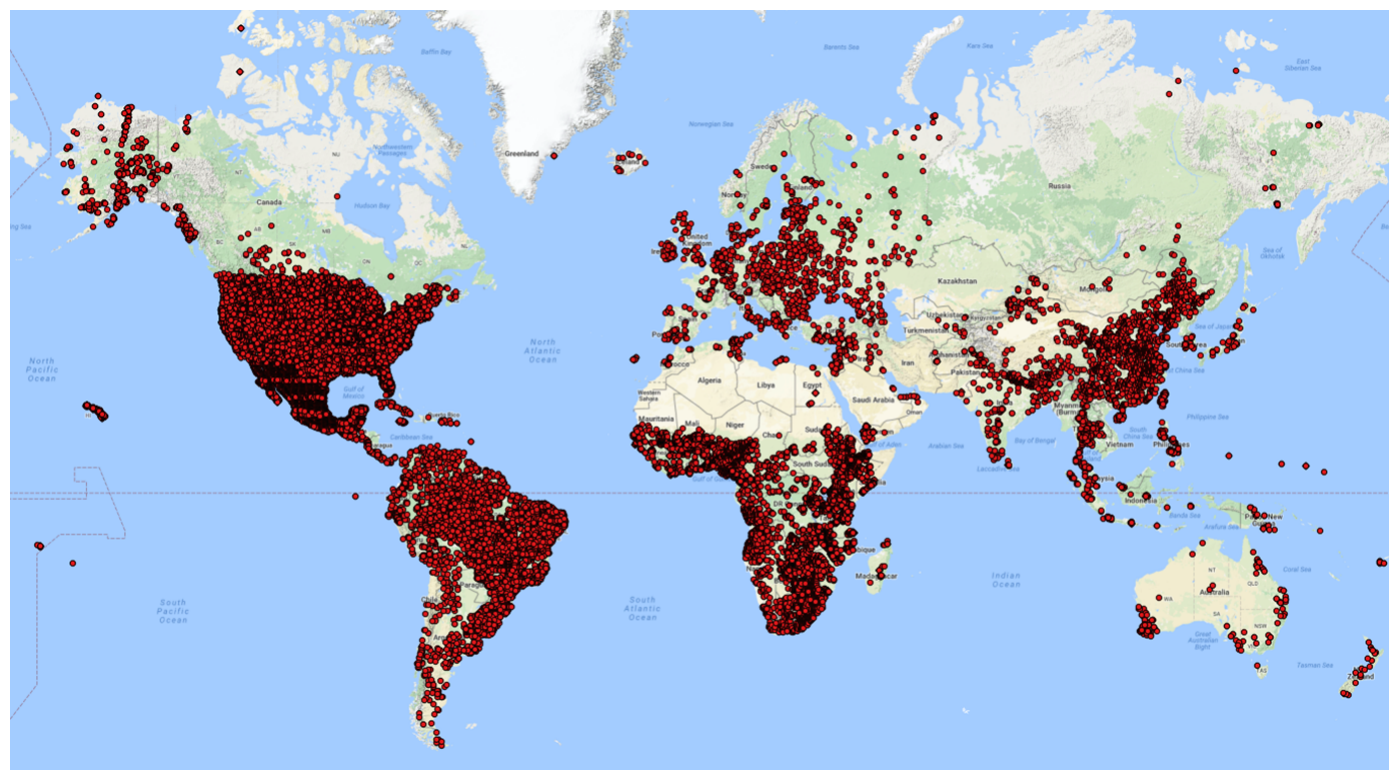

Figure 4. Location of soil profiles provided in the "July 2016" snapshot of WoSIS. (See Appendix C for the number of profiles by country.)

SoilIE, undertaken in the second half of 2015, had the objective of developing and testing a soil standard that harmonised existing standards for data exchange defined in Europe and Oceania. During SoilIE, partners from Europe and Oceania mapped their test data to the SoilML format. Multiple OGC WFSs providing data in SoilML format were established, allowing for on-line derivation of new data (e.g. using pedotransfer functions). SoillE was successful in accessing data in multiple clients (servers) from several soil data providers, each using their own software configurations (Ritchie, 2016). Further collaboration will involve refinements to the SoilML schema, Resource Description Foundation (RDF) vocabularies, linked data, and other remaining issues.

Use of OGC web services and modelling data in XML is necessary for fulfilment of compliance requirements with regional interoperability initiatives (INSPIRE, 2015; GS Soil, 2008; Wilson, 2016). The output of the data can then be customised between different XML standards using Extensible Stylesheet Language (XSL) templates or using server schema mapping.

The above activities in support of a global soil SDI were initiated by the GlobalSoilMap consortium in Wageningen, 2009, and may be consolidated within the framework of the Global Soil Partnership (FAO-GSP, 2014a, b; IUSS WG-SIS, 2015) and related interoperability efforts in other domains (e.g. Porter et al., 2015; GEOSS, 2012; GODAN, 2015).

\section{Data availability}

Version WoSIS_2016_July (Batjes et al., 2016), as described in this paper, is archived for long-term storage at ISRIC -
World Soil Information, the World Data Center (WDC) for Soils of the ICSU World Data System; it may be accessed freely through doi:10.17027/isric-wdcsoils.20160003. The zip file (32 MB) includes a detailed "readme first" file that describes key aspects of the dataset.

\section{Conclusions}

Bringing disparate soil databases from numerous sources under a common standard poses many and diverse challenges. So far, the focus in WoSIS has been on the standardisation of soil property definitions, soil analytical method descriptions, and soil property values in order to serve consistent, quality-assessed data that have been observed or measured according to analytical procedures (aggregates) that are functionally comparable.

Future releases of WoSIS-served data will consider a wider selection of soil site and layer properties, assessed by conventional soil analytical procedures as well as by soil spectroscopy. Further, grid and polygon maps will be gradually added to the server database. Each release (snapshot) will be given a unique time stamp and DOI.

The WoSIS server database forms an important building block of ISRIC's evolving spatial data infrastructure. Instrumental to enhanced usability of the data served by WoSIS will be the actual harmonisation of soil property values as well as the further standardisation of identifiers and descriptions of soil analytical procedures. Development of corresponding interfaces will allow for the fulfilment of future exchange of, and demands, for global soil information and enable further processing of soil data shared by contributing parties. 
WoSIS-related activities are already catalysing institutional collaboration with institutes in Africa, Europe, and Latin America. Capacity building and cooperation among (inter)national soil institutes around the world is essential to create and share ownership of the soil information newly derived from the shared data, as well as to strengthen the necessary expertise and capacity to further develop and test the world soil information service worldwide. 


\section{Appendix A}

Table A1. Naming conventions and descriptions of variables provided in the "WOSIS July 2016" snapshot.

\begin{tabular}{|c|c|c|c|c|c|}
\hline Code* & Attribute & Unit & Profiles & Layers & Description \\
\hline BDFI & Bulk density, fine earth & $\mathrm{kg} \mathrm{dm}^{-3}$ & 20727 & 105848 & Bulk density of the fine earth fraction $<\mathrm{mm}\left(\mathrm{kg} \mathrm{dm}^{-3}\right)$ \\
\hline BDWS & Bulk density, whole soil & $\mathrm{kg} \mathrm{dm}^{-3}$ & 25909 & 153568 & $\begin{array}{l}\text { Bulk density of the whole soil including coarse fragments } \\
\left(\mathrm{kg} \mathrm{dm}^{-3}\right)\end{array}$ \\
\hline TCEQ & Calcium carbonate equivalent total & $\mathrm{g} \mathrm{kg}^{-1}$ & 27809 & 115448 & $\begin{array}{l}\text { The content of carbonate in a liming material or calcare- } \\
\text { ous soil calculated as if all of the carbonate is in the form } \\
\text { of } \mathrm{CaCO}_{3}\left(\mathrm{~g} \mathrm{~kg}^{-1} \text { in the fine earth fraction }<2 \mathrm{~mm}\right) \text {; also } \\
\text { known as inorganic carbon }\end{array}$ \\
\hline CECX & Cation exchange capacity (CEC) & $\mathrm{cmol}_{(\mathrm{c})} \mathrm{kg}^{-1}$ & 48461 & 273346 & $\begin{array}{l}\text { Capacity of the fine earth fraction }<2 \mathrm{~mm} \text { to hold ex- } \\
\text { changeable cations, estimated by buffering the soil at spec- } \\
\text { ified } \mathrm{pH}\left(\text { e.g. } \mathrm{pH} 7 \text { or } \mathrm{pH} 8 ; \mathrm{cmol}_{\mathrm{c}} \mathrm{kg}^{-1} \text { ) }\right.\end{array}$ \\
\hline CLAY & Clay total & $\mathrm{g} \mathrm{kg}^{-1}$ & 80082 & 408452 & $\begin{array}{l}\text { Gravimetric content of }<0.002 \mathrm{~mm} \text { soil material in the fine } \\
\text { earth fraction }<2 \mathrm{~mm}(\mathrm{~g} / 100 \mathrm{~g})\end{array}$ \\
\hline CFGR & Coarse fragments, gravimetric total & $10^{-2} \mathrm{~g} \mathrm{~g}^{-1}$ & 27050 & 159206 & $\begin{array}{l}\text { Gravimetric content of coarse fragments }>2 \mathrm{~mm} \text { in the } \\
\text { whole soil }(\mathrm{g} / 100 \mathrm{~g})\end{array}$ \\
\hline $\mathrm{CFVO}$ & Coarse fragments, volumetric total & $10^{-2} \mathrm{~cm}^{3} \mathrm{~cm}^{-3}$ & 37280 & 198534 & $\begin{array}{l}\text { Volumetric content of the coarse fragments }>2 \mathrm{~mm} \text { in the } \\
\text { whole soil }\left(\mathrm{cm}^{3} / 100 \mathrm{~cm}^{3}\right)\end{array}$ \\
\hline ECEC & Effective cation exchange capacity (ECEC) & $\mathrm{cmol}_{(\mathrm{c})} \mathrm{kg}^{-1}$ & 23189 & 102665 & $\begin{array}{l}\text { Capacity of the fine earth fraction }<2 \mathrm{~mm} \text { to hold } \\
\text { exchangeable cations at the } \mathrm{pH} \text { of the soil (ECEC, } \\
\mathrm{cmol}_{\mathrm{c}} \mathrm{kg}^{-1} \text { ); conventionally approximated by summation } \\
\text { of exchangeable bases }\left(\mathrm{Ca}^{2+}, \mathrm{Mg}^{2+}, \mathrm{K}^{+}, \text {and } \mathrm{Na}^{+} \text {) plus }\right. \\
1 \mathrm{~N} \mathrm{KCl} \text { exchangeable acidity }\left(\mathrm{Al}^{3+} \text { and } \mathrm{H}^{+}\right) \text {in acidic soils }\end{array}$ \\
\hline ELCO & Electrical conductivity & $\mathrm{dS} \mathrm{m}^{-1}$ & 28266 & 120039 & $\begin{array}{l}\text { Ability of a } 1: x \text { soil water extract to conduct electrical cur- } \\
\text { rent }\left(\mathrm{EC}_{x}, \mathrm{dS} \mathrm{m}^{-1}\right) ; \mathrm{EC}_{\mathrm{e}} \text { refers to values measured in a sat- } \\
\text { urated soil extract }\end{array}$ \\
\hline ORGC & Organic carbon & $\mathrm{g} \mathrm{kg}^{-1}$ & 64118 & 315362 & $\begin{array}{l}\text { Gravimetric content of organic carbon in the fine earth frac- } \\
\text { tion }\end{array}$ \\
\hline PHCA & $\mathrm{pH} \mathrm{CaCl} 2$ & unitless & 39074 & 237756 & $\begin{array}{l}\text { A measure of the acidity or alkalinity in soils, defined as the } \\
\text { negative logarithm (base } 10 \text { ) of the activity of hydronium } \\
\text { ions }\left(\mathrm{H}^{+}\right) \text {in a } \mathrm{CaCl}_{2} \text { solution, as specified in the analytical } \\
\text { method descriptions (dimensionless) }\end{array}$ \\
\hline PHAQ & $\mathrm{pH} \mathrm{H}_{2} \mathrm{O}$ & unitless & 79118 & 407226 & $\begin{array}{l}\text { A measure of the acidity or alkalinity in soils, defined as the } \\
\text { negative logarithm (base } 10) \text { of the activity of hydronium } \\
\text { ions }\left(\mathrm{H}^{+}\right) \text {in water (dimensionless) }\end{array}$ \\
\hline PHKC & $\mathrm{pH} \mathrm{KCl}$ & unitless & 19064 & 88127 & $\begin{array}{l}\text { A measure of the acidity or alkalinity in soils, defined as the } \\
\text { negative logarithm (base } 10 \text { ) of the activity of hydronium } \\
\text { ions }\left(\mathrm{H}^{+}\right) \text {in a } \mathrm{KCl} \text { solution, as specified in the analytical } \\
\text { method descriptions (dimensionless) }\end{array}$ \\
\hline PHNF & $\mathrm{pH} \mathrm{NaF}$ & unitless & 4866 & 24917 & $\begin{array}{l}\text { A measure of the acidity or alkalinity in soils, defined as the } \\
\text { negative logarithm (base } 10 \text { ) of the activity of hydronium } \\
\text { ions }\left(\mathrm{H}^{+}\right) \text {in a NaF solution, as specified in the analytical } \\
\text { method descriptions (dimensionless) }\end{array}$ \\
\hline SAND & Sand total & $10^{-2} \mathrm{~g} \mathrm{~g}^{-1}$ & 78402 & 398573 & $\begin{array}{l}\text { Larger than } Y \mathrm{~mm} \text { fraction of the }<2 \mathrm{~mm} \text { soil material } \\
(\mathrm{g} / 100 \mathrm{~g} \text { ); esd (equivalent spherical diameter), } Y \text { as speci- } \\
\text { fied in the analytical method descriptions }\end{array}$ \\
\hline SILT & Silt total & $10^{-2} \mathrm{gg}^{-1}$ & 79331 & 406502 & $\begin{array}{l}0.002 \mathrm{~mm} \text { to } Y \mathrm{~mm} \text { fraction of the }<2 \mathrm{~mm} \text { soil material } \\
(\mathrm{g} / 100 \mathrm{~g} \text { ); esd (equivalent spherical diameter), } X \text { respec- } \\
\text { tively } Y \text { as specified in the analytical method descriptions }\end{array}$ \\
\hline CFAO & Soil classification, FAO & unitless & 24894 & 24894 & $\begin{array}{l}\text { Classification of the soil profile according to specified edi- } \\
\text { tion (year) of the FAO/Unesco Legend, up to soil unit level } \\
\text { when available }\end{array}$ \\
\hline CSTX & Soil classification, soil taxonomy & unitless & 21614 & 21614 & $\begin{array}{l}\text { Classification of the soil profile according to specified edi- } \\
\text { tion (year) of USDA Soil Taxonomy, up to subgroup level } \\
\text { when available }\end{array}$ \\
\hline CWRB & Soil classification, WRB & unitless & 24628 & 24628 & $\begin{array}{l}\text { Classification of the soil profile according to specified edi- } \\
\text { tion (year) of the World Reference Base for Soil Resources } \\
\text { (WRB), up to qualifier level when available }\end{array}$ \\
\hline тотС & Total carbon & $\mathrm{g} \mathrm{kg}^{-1}$ & 14094 & 70687 & $\begin{array}{l}\text { Gravimetric content of organic carbon and inorganic carbon } \\
\text { in the fine earth fraction }<2 \mathrm{~mm}_{\left(\mathrm{g} \mathrm{kg}^{-1}\right)}\end{array}$ \\
\hline WRGR & Water retention, gravimetric & $10^{-2} \mathrm{~g} \mathrm{~g}^{-1}$ & 28701 & 173972 & $\begin{array}{l}\text { Soil moisture content by weight, at the tension specified in } \\
\text { the analytical method descriptions }(\mathrm{g} / 100 \mathrm{~g})\end{array}$ \\
\hline WRVO & Water retention, volumetric & $10^{-2} \mathrm{~cm}^{3} \mathrm{~cm}^{-3}$ & 17124 & 82695 & $\begin{array}{l}\text { Soil moisture content by volume, at the tension specified in } \\
\text { the analytical method descriptions }\left(\mathrm{cm}^{3} / 100 \mathrm{~cm}^{3}\right)\end{array}$ \\
\hline
\end{tabular}

* A full complement of all these attributes is generally not available for many profiles (see text). 
Appendix B: Structure of the "July 2016" WoSIS snapshot

This appendix describes the structure of the data files presented in the "July 2016" WoSIS snapshot:

- wosis_201607_attributes.txt,

- wosis_201607_profiles.txt,

- wosis_201607_layers.txt.

The first file lists the four-letter code for each attribute, a short explanation, and the units of measurement (Appendix A). This file also gives the number of profiles and layers in the present snapshot.

The second file lists the unique profile ID (i.e. primary key), country name and ISO country code, geometric accuracy, latitude and longitude (WGS 1984), and information on the soil classification system and edition. Depending on the soil classification system used, the number of fields will vary. For example, for US soil taxonomy, coded here as "cstx", these are order, suborder, great group, and subgroup, as indicated in the column headings.

The third and largest file lists all the soil properties by layer and profile to enhance user-friendliness. It starts as follows:
profile_id
identifier for profile, links to file wosis_201607_profiles;
profile_layer_id unique identifier for layer for given profile (primary key);
top upper depth of layer (or horizon);
bottom lower depth of layer.

Subsequently, the following items are listed sequentially per attribute ("xxxx") as defined under "code" in file wosis_201607_attributes.txt: xxxx_value

xxxx_value_avg
xxxx_method
xxxx_date
xxxx_dataset_id
xxxx_profile_code
xxxx_licenset

array listing all values for soil property "xxxx" for the given layer; thus, more than one observation can be reported when available, for example three values for ORGC: $\{1: 5.5,2: 10.1,3: 8.5\}$; average, for above (use this value for "routine" modelling);

array listing the method descriptions for each value;

array listing the date of observation for each value;

abbreviation for source dataset (e.g. WD-ISIS);

code for given profile; licence for given data (CC-BY-NC or CC-BY);

as above, but for the next attribute.
All fields in the above files are tab-delimited, while double quotation marks serve as text delimiters; file coding is according to the UTF-8 Unicode transformation format. As such, the files can be easily imported into an SQL database or statistical software such as R, after which they may be joined using the unique profile_id. 


\section{Appendix C}

Table C1. Number of profiles by country and continent.

\begin{tabular}{|c|c|c|c|c|c|}
\hline Continent & Country name & $\begin{array}{l}\text { ISO } \\
\text { code }\end{array}$ & $\begin{array}{r}N \text { of } \\
\text { profiles }\end{array}$ & $\begin{array}{r}\text { Area } \\
\left(\mathrm{km}^{2}\right)\end{array}$ & $\begin{array}{l}\text { Profile density } \\
\text { (per } 1000 \mathrm{~km}^{2} \text { ) }\end{array}$ \\
\hline \multirow[t]{44}{*}{ Africa } & Algeria & $\mathrm{DZ}$ & 4 & 2308647 & 0.002 \\
\hline & Angola & $\mathrm{AO}$ & 1035 & 1246690 & 0.830 \\
\hline & Benin & BJ & 738 & 115247 & 6.404 \\
\hline & Botswana & BW & 898 & 578247 & 1.553 \\
\hline & Burkina Faso & $\mathrm{BF}$ & 887 & 273281 & 3.246 \\
\hline & Burundi & $\mathrm{BI}$ & 36 & 26857 & 1.340 \\
\hline & Cameroon & $\mathrm{CM}$ & 455 & 465363 & 0.978 \\
\hline & Central African Republic & $\mathrm{CF}$ & 87 & 619591 & 0.140 \\
\hline & Chad & $\mathrm{TD}$ & 5 & 1265392 & 0.004 \\
\hline & Congo & CG & 70 & 340599 & 0.206 \\
\hline & Côte d'Ivoire & $\mathrm{CI}$ & 254 & 321762 & 0.789 \\
\hline & Dem. Rep. of the Congo & $\mathrm{CD}$ & 374 & 2329162 & 0.161 \\
\hline & Egypt & EG & 22 & 982161 & 0.022 \\
\hline & Ethiopia & ET & 1583 & 1129314 & 1.402 \\
\hline & Gabon & GA & 46 & 264022 & 0.174 \\
\hline & Ghana & $\mathrm{GH}$ & 163 & 238842 & 0.682 \\
\hline & Guinea & GN & 62 & 243023 & 0.255 \\
\hline & Guinea-Bissau & GW & 18 & 30740 & 0.586 \\
\hline & Kenya & $\mathrm{KE}$ & 504 & 582342 & 0.865 \\
\hline & Lesotho & LS & 33 & 30453 & 1.084 \\
\hline & Liberia & LR & 48 & 96103 & 0.499 \\
\hline & Libya & LY & 14 & 1620583 & 0.009 \\
\hline & Madagascar & MG & 52 & 588834 & 0.088 \\
\hline & Malawi & MW & 2985 & 118715 & 25.144 \\
\hline & Mali & ML & 756 & 1251471 & 0.604 \\
\hline & Mauritania & MR & 11 & 1038527 & 0.011 \\
\hline & Morocco & MA & 27 & 414030 & 0.065 \\
\hline & Mozambique & $\mathrm{MZ}$ & 275 & 787305 & 0.349 \\
\hline & Namibia & NA & 62 & 823989 & 0.075 \\
\hline & Niger & $\mathrm{NE}$ & 488 & 1182602 & 0.413 \\
\hline & Nigeria & NG & 1203 & 908978 & 1.323 \\
\hline & Rwanda & RW & 92 & 25388 & 3.624 \\
\hline & Senegal & SN & 311 & 196200 & 1.585 \\
\hline & Sierra Leone & SL & 12 & 72281 & 0.166 \\
\hline & Somalia & SO & 245 & 632562 & 0.387 \\
\hline & South Africa & $\mathrm{ZA}$ & 649 & 1220127 & 0.532 \\
\hline & Sudan & SD & 116 & 1843196 & 0.063 \\
\hline & Swaziland & $\mathrm{SZ}$ & 14 & 17290 & 0.810 \\
\hline & Togo & TG & 9 & 56767 & 0.159 \\
\hline & Tunisia & $\mathrm{TN}$ & 60 & 155148 & 0.387 \\
\hline & Uganda & UG & 12 & 241495 & 0.050 \\
\hline & United Republic of Tanzania & $\mathrm{TZ}$ & 1647 & 939588 & 1.753 \\
\hline & Zambia & $\mathrm{ZM}$ & 472 & 751063 & 0.628 \\
\hline & Zimbabwe & $\mathrm{ZW}$ & 319 & 390648 & 0.817 \\
\hline Antarctica & Antarctica & AQ & 9 & 12537967 & 0.001 \\
\hline \multirow[t]{9}{*}{ Asia } & Afghanistan & $\mathrm{AF}$ & 19 & 641827 & 0.030 \\
\hline & Armenia & $\mathrm{AM}$ & 6 & 29624 & 0.203 \\
\hline & Azerbaijan & $\mathrm{AZ}$ & 4 & 164780 & 0.024 \\
\hline & Bahrain & $\mathrm{BH}$ & 2 & 673 & 2.970 \\
\hline & Bangladesh & $\mathrm{BD}$ & 16 & 139825 & 0.114 \\
\hline & Bhutan & BT & 80 & 37674 & 2.123 \\
\hline & China & $\mathrm{CN}$ & 1490 & 9345214 & 0.159 \\
\hline & Georgia & GE & 9 & 69785 & 0.129 \\
\hline & India & IN & 139 & 2961118 & 0.047 \\
\hline
\end{tabular}


Table C1. Continued.

\begin{tabular}{|c|c|c|c|c|c|}
\hline Continent & Country name & $\begin{array}{l}\text { ISO } \\
\text { code }\end{array}$ & $\begin{array}{r}N \text { of } \\
\text { profiles }\end{array}$ & $\begin{array}{r}\text { Area } \\
\left(\mathrm{km}^{2}\right)\end{array}$ & $\begin{array}{l}\text { Profile density } \\
\left(\text { per } 1000 \mathrm{~km}^{2}\right)\end{array}$ \\
\hline & Indonesia & ID & 108 & 1888620 & 0.057 \\
\hline & Iran (Islamic Republic of) & IR & 2 & 1677319 & 0.001 \\
\hline & Iraq & IQ & 14 & 435864 & 0.032 \\
\hline & Israel & IL & 16 & 20720 & 0.772 \\
\hline & Japan & JP & 39 & 373651 & 0.104 \\
\hline & Jordan & $\mathrm{JO}$ & 40 & 89063 & 0.449 \\
\hline & Lebanon & LB & 6 & 10136 & 0.592 \\
\hline & Malaysia & MY & 46 & 329775 & 0.139 \\
\hline & Mongolia & $\mathrm{MN}$ & 7 & 1564529 & 0.004 \\
\hline & Nepal & NP & 141 & 147437 & 0.956 \\
\hline & Oman & $\mathrm{OM}$ & 9 & 308335 & 0.029 \\
\hline & Pakistan & $\mathrm{PK}$ & 43 & 788439 & 0.055 \\
\hline & Philippines & $\mathrm{PH}$ & 68 & 296031 & 0.230 \\
\hline & Republic of Korea & $\mathrm{KR}$ & 17 & 99124 & 0.172 \\
\hline & Sri Lanka & LK & 13 & 66173 & 0.196 \\
\hline & Syrian Arab Republic & SY & 66 & 188128 & 0.351 \\
\hline & Taiwan & TW & 33 & 36127 & 0.913 \\
\hline & Tajikistan & $\mathrm{TJ}$ & 5 & 142004 & 0.035 \\
\hline & Thailand & $\mathrm{TH}$ & 285 & 515417 & 0.553 \\
\hline & Turkey & TR & 68 & 781229 & 0.087 \\
\hline & United Arab Emirates & $\mathrm{AE}$ & 6 & 71079 & 0.084 \\
\hline & Uzbekistan & $\mathrm{UZ}$ & 8 & 449620 & 0.018 \\
\hline & Yemen & YE & 284 & 453596 & 0.626 \\
\hline \multirow[t]{31}{*}{ Europe } & Albania & $\mathrm{AL}$ & 63 & 28682 & 2.197 \\
\hline & Belarus & BY & 94 & 207581 & 0.453 \\
\hline & Belgium & $\mathrm{BE}$ & 190 & 30669 & 6.195 \\
\hline & Bulgaria & BG & 45 & 111300 & 0.404 \\
\hline & Czech Republic & $\mathrm{CZ}$ & 38 & 78845 & 0.482 \\
\hline & Denmark & DK & 20 & 44458 & 0.450 \\
\hline & Estonia & $\mathrm{EE}$ & 123 & 45441 & 2.707 \\
\hline & Finland & FI & 24 & 336892 & 0.071 \\
\hline & France & FR & 53 & 548785 & 0.097 \\
\hline & Germany & $\mathrm{DE}$ & 51 & 357227 & 0.143 \\
\hline & Greece & GR & 11 & 132549 & 0.083 \\
\hline & Hungary & $\mathrm{HU}$ & 61 & 93119 & 0.655 \\
\hline & Iceland & IS & 11 & 102566 & 0.107 \\
\hline & Ireland & $\mathrm{IE}$ & 36 & 69809 & 0.516 \\
\hline & Italy & IT & 86 & 301651 & 0.285 \\
\hline & Latvia & LV & 10 & 64563 & 0.155 \\
\hline & Lithuania & LT & 18 & 64943 & 0.277 \\
\hline & Luxembourg & $\mathrm{LU}$ & 128 & 2621 & 48.842 \\
\hline & Netherlands & NL & 192 & 35203 & 5.454 \\
\hline & Norway & NO & 10 & 324257 & 0.031 \\
\hline & Poland & PL & 128 & 311961 & 0.410 \\
\hline & Portugal & PT & 35 & 91876 & 0.381 \\
\hline & Republic of Moldova & MD & 32 & 33798 & 0.947 \\
\hline & Romania & RO & 43 & 238118 & 0.181 \\
\hline & Russian Federation & RU & 156 & 16998830 & 0.009 \\
\hline & Slovakia & SK & 40 & 49072 & 0.815 \\
\hline & Spain & ES & 42 & 505752 & 0.083 \\
\hline & Sweden & SE & 26 & 449212 & 0.058 \\
\hline & Switzerland & $\mathrm{CH}$ & 10 & 41257 & 0.242 \\
\hline & Ukraine & UA & 79 & 600526 & 0.132 \\
\hline & United Kingdom & GB & 53 & 244308 & 0.217 \\
\hline
\end{tabular}


Table C1. Continued.

\begin{tabular}{|c|c|c|c|c|c|}
\hline Continent & Country name & $\begin{array}{l}\text { ISO } \\
\text { code }\end{array}$ & $\begin{array}{r}N \text { of } \\
\text { profiles }\end{array}$ & $\begin{array}{r}\text { Area } \\
\left(\mathrm{km}^{2}\right)\end{array}$ & $\begin{array}{l}\text { Profile density } \\
\left(\text { per } 1000 \mathrm{~km}^{2}\right)\end{array}$ \\
\hline \multirow[t]{19}{*}{ North America } & Barbados & BB & 3 & 433 & 6.928 \\
\hline & Belize & $\mathrm{BZ}$ & 21 & 21764 & 0.965 \\
\hline & Canada & $\mathrm{CA}$ & 148 & 9875646 & 0.015 \\
\hline & Costa Rica & $\mathrm{CR}$ & 55 & 51042 & 1.078 \\
\hline & Cuba & $\mathrm{CU}$ & 52 & 110863 & 0.469 \\
\hline & Dominican Republic & DO & 1 & 48099 & 0.021 \\
\hline & El Salvador & SV & 9 & 20732 & 0.434 \\
\hline & Greenland & GL & 5 & 2165159 & 0.002 \\
\hline & Guatemala & GT & 22 & 109062 & 0.202 \\
\hline & Honduras & $\mathrm{HN}$ & 11 & 112124 & 0.098 \\
\hline & Jamaica & $\mathrm{JM}$ & 76 & 10965 & 6.931 \\
\hline & Mexico & MX & 12223 & 1949527 & 6.270 \\
\hline & Netherlands Antilles & $\mathrm{AN}$ & 4 & 790 & 5.066 \\
\hline & Nicaragua & NI & 26 & 128376 & 0.203 \\
\hline & Panama & PA & 25 & 74850 & 0.334 \\
\hline & Puerto Rico & PR & 30 & 8937 & 3.357 \\
\hline & Trinidad and Tobago & TT & 2 & 5144 & 0.389 \\
\hline & United States of America & US & 50361 & 9315946 & 5.406 \\
\hline & United States Virgin Islands & VI & 3 & 352 & 8.514 \\
\hline \multirow[t]{8}{*}{ Oceania } & Australia & $\mathrm{AU}$ & 142 & 7687634 & 0.018 \\
\hline & Cook Islands & $\mathrm{CK}$ & 1 & 241 & 4.142 \\
\hline & Fiji & FJ & 9 & 18293 & 0.492 \\
\hline & Micronesia (Feder. States of) & FM & 14 & 740 & 18.917 \\
\hline & New Zealand & $\mathrm{NZ}$ & 20 & 270415 & 0.074 \\
\hline & Papua New Guinea & PG & 31 & 462230 & 0.067 \\
\hline & Samoa & WS & 17 & 2835 & 5.996 \\
\hline & Solomon Islands & SB & 1 & 28264 & 0.035 \\
\hline \multirow[t]{12}{*}{ South America } & Argentina & $\mathrm{AR}$ & 238 & 2780175 & 0.086 \\
\hline & Bolivia (Plurinational State of) & $\mathrm{BO}$ & 77 & 1084491 & 0.071 \\
\hline & Brazil & $\mathrm{BR}$ & 7842 & 8485946 & 0.924 \\
\hline & Chile & CL & 45 & 753355 & 0.060 \\
\hline & Colombia & $\mathrm{CO}$ & 166 & 1137939 & 0.146 \\
\hline & Ecuador & $\mathrm{EC}$ & 77 & 256249 & 0.300 \\
\hline & French Guiana & GF & 7 & 83295 & 0.084 \\
\hline & Guyana & GY & 43 & 211722 & 0.203 \\
\hline & Peru & PE & 147 & 1290640 & 0.114 \\
\hline & Suriname & SR & 27 & 145100 & 0.186 \\
\hline & Uruguay & UY & 131 & 177811 & 0.737 \\
\hline & Venezuela (Bolivarian Rep. of) & $\mathrm{VE}$ & 170 & 912025 & 0.186 \\
\hline World & World (total) & WD & 94441 & 137770610 & 0.685 \\
\hline
\end{tabular}

Note: country names and areas are based on the Global Administrative Layers (GAUL) database; see http://www.fao.org/geonetwork/srv/en/metadata.show?id=12691. 
Acknowledgement. The development of WoSIS has been made possible thanks to the contributions and shared knowledge of a steadily growing number of data providers, including soil survey organisations, research institutes, and individual experts, whose contributions are gratefully acknowledged. A detailed list of data providers is available at http://www.isric.org/content/ wosis-cooperating-institutions-and-experts for details. We also thank the reviewers for their insightful comments.

Edited by: D. Carlson

Reviewed by: G. Hugelius and A. Samuel-Rosa

\section{References}

Arrouays, D., Grundy, M. G., Hartemink, A. E., Hempel, J. W., Heuvelink, G. B. M., Hong, S. Y., Lagacherie, P., Lelyk, G., McBratney, A. B., McKenzie, N. J., Mendonca-Santos, M. d. L., Minasny, B., Montanarella, L., Odeh, I. O. A., Sanchez, P. A., Thompson, J. A., Zhang, G.-L., and Donald, L. S.: GlobalSoilMap: Toward a Fine-Resolution Global Grid of Soil Properties, Adv. Agron., 125, 93-134, doi:10.1016/B978-0-12-8001370.00003-0, 2014.

Baritz, R., Erdogan, H., Fujii, K., Takata, Y., Nocita, M., Bussian, B., Batjes, N. H., Hempel, J., Wilson, P., and Vargas, R.: Harmonization of methods, measurements and indicators for the sustainable management and protection of soil resources (Providing mechanisms for the collation, analysis and exchange of consistent and comparable global soil data and information), Global Soil Partnership, FAO, 44 pp., 2014.

Batjes, N. H.: World Inventory of Soil Emission Potentials: WISE 2.1 - Profile database user manual and coding protocols, ISRIC, Wageningen. Tech. Pap. 26, 56 pp., 1995.

Batjes, N. H.: Harmonized soil profile data for applications at global and continental scales: updates to the WISE database, Soil Use Manage., 25, 124-127 doi:10.1111/j.1475-2743.2009.00202.x, 2009.

Batjes, N. H.: Harmonised soil property values for broad-scale modelling (WISE30sec) with estimates of global soil carbon stocks, Geoderma, 269, 61-68, doi:10.1016/j.geoderma.2016.01.034, 2016.

Batjes, N. H., Ribeiro, E., van Oostrum, A., Leenaars, J., and Jesus de Mendes, J.: Standardised soil profile data for the world (WoSIS, July 2016 snapshot), doi:10.727/isricwdcsoils.2016003, 2016.

Chapman, A. D.: Principles of Data Quality, version 1.0, Global Biodiversity Information Facility, Copenhagen, Copenhagen, 58 pp., 2005.

FAO-GSP: Plan of action for Pillar Four of the Global Soil Partnership: Building an enduring and authoritative global system to monitor and forecast the condition of the Earth's soil resources FAO Global Soil Partnership, Rome, 33 pp., 2014a.

FAO-GSP: Plan of Action for Pillar Five of the Global Soil Partnership: Harmonization of methods, measurements and indicators for the sustainable management and protection of soil resources, FAO Global Soil Partnership, Rome, 37 pp., 2014b.

FAO and ITPS: Status of the world's soil resources (SWSR) - Main report, Food and Agriculture Organization of the United Nations and Intergovernmental Technical Panel on Soils, Rome, 650 pp., 2015.
GEO: GEOSS data sharing action plan, Group on Earth Obsertvations, Geneva, 8 pp., 2010.

Global Earth Observation System of Systems (GEOSS): available at: http://www.earthobservations.org/geoss.shtml (last access: 14 October 2016), 2012.

GlobalSoilMap: Specifications Version 1 GlobalSoilMap.net products (Release 2.1), 50 pp., 2013.

GODAN: How can we improve agriculture, food and nutrition with open data?, Open Data Institute London. Report UK20150528, 33 pp., 2015.

GS Soil: Discover INSPIRE compliant harmonised soil data and services, GS Soil Consortium, Paris-Lodon University Salzburg GS Soil 06/2009-05-2012, 60 pp., 2008.

Hendriks, C. M. J., Stoorvogel, J. J., and Claessens, L.: Exploring the challenges with soil data in regional land use analysis, Agr. Syst., 144, 9-21, doi:10.1016/j.agsy.2016.01.007, 2016.

Hengl, T., Mendes de Jesus, J., MacMillan, R. A., Batjes, N. H., Heuvelink, G. B. M., Ribeiro, E. C., SamuelRosa, A., Kempen, B., Leenaars, J. G. B., Walsh, M. G., and Gonzalez, M. R.: SoilGrids $1 \mathrm{~km}$ - global soil information based on automated mapping, PLoS ONE, 9, e105992, doi:10.1371/journal.pone.0105992, 2014.

Hengl, T., Heuvelink, G. B. M., Kempen, B., Leenaars, J. G. B., Walsh, M. G., Shepherd, K. D., Sila, A., MacMillan, R. A., Mendes de Jesus, J., Tamene, L., and Tondoh, J. E.: Mapping Soil Properties of Africa at $250 \mathrm{~m}$ Resolution: Random Forests Significantly Improve Current Predictions, PLoS ONE, 10, e0125814, doi:10.1371/journal.pone.0125814, 2015.

Hengl, T., Mendes de Jesus, J., Heuvelink, G. B. M., Ruiperez Gonzalez, M., Kilibarda, M., Blagotic, A., Shangguan, W., Wright, M. N., Geng, X., Bauer-Marschallinger, B., Guevara, M. A., Vargas, R., MacMillan, R. A., Batjes, N. H., Leenaars, J. G. B., Wheeler, I., Mantel, S., and Kempen, B.: SoilGrids250 m: Global gridded soil information based on machine learning, PLoS ONE, available at: http://gsif.isric.org/lib/exe/fetch.php?media=wiki: soilgrids250m_global_gridded_preprint.pdf (Last access: 22 December 2016), 2016.

INSPIRE Data specifications - Infrastructure for spatial information in the European Community, available at: http://inspire.ec. europa.eu/index.cfm/pageid/2 (last access: 25 April 2016), 2015.

ISO 10390:2005: Soil quality - Determination of $\mathrm{pH}$, available at: http://www.iso.org/iso/catalogue_detail.htm?csnumber= 40879 (last access: 10 October 2016), 2015.

ISRIC Soil Information System (ISIS): available at: http://isis.isric. org/ (last access: 23 June 2016), 2015.

ISRIC: Data and Software Policy, ISRIC - World Soil Information (WDC - Soils) Wageningen, 6 pp., 2016.

IUSS Working Group on Soil Information Standards available at: http://www.soilinformationstandards.org/ (last access: 12 March 2016), 2015.

Jankauskas, B., Jankauskiene, G., Slepetiene, A., Fullen, M. A., and Booth, C. A.: International comparison of analytical methods of determining the soil organic matter content of Lithuanian eutric Albeluvisols, Commun. Soil Sci. Plan., 37, 707-720, doi:10.1080/00103620600563499, 2006.

Jones, P. G. and Thornton, P. K.: Representative soil profiles for the Harmonized World Soil Database at different spatial resolutions for agricultural modelling applications, Agr. Syst., 139, 93-99, doi:10.1016/j.agsy.2015.07.003, 2015. 
Kroll, B. G. C. M.: Towards a data management framework for digital soil mapping with limited data, in: Digital soil mapping with limited data, edited by: Hartemink, A. E., McBratney, A., and Mendoca Santos, M. L., Springer, 137-149, 2008.

Landon, J. R.: Booker Tropical Soil Manual, Longman Scientific \& Technical, New York, 474 pp., 1991.

Leenaars, J. G. B.: Africa Soil Profiles Database - A compilation of georeferenced and standardised legacy soil profile data for Sub Saharan Africa (version 1.1), Africa Soil Information Service (AfSIS) and ISRIC - World Soil Information, Wageningen. Report 2013/03, 160 pp., 2013.

Leenaars, J. G. B., Kempen, B., van Oostrum, A. J. M., and Batjes, N. H.: Africa Soil Profiles Database: a compilation of georeferenced and standardised legacy soil profile data for Sub-Saharan Africa GlobalSoilMap - Basis of the global spatial information system, Orléans, 51-57, 2014.

Lettens, S., Vos, B. D., Quataert, P., van Wesemael, B., Muys, B., and van Orshoven, J.: Variable carbon recovery of Walkley-Black analysis and implications for national soil organic carbon accounting, Eur. J. Soil Sci. 58, 1244-1253, doi:10.1111/j.13652389.2007.00916.x, 2007.

Luo, Y., Ahlström, A., Allison, S. D., Batjes, N. H., Brovkin, V., Carvalhais, N., Chappell, A., Ciais, P., Davidson, E. A., Finzi, A., Georgiou, K., Guenet, B., Hararuk, O., Harden, J. W., He, Y., Hopkins, F. M., Jiang, L., Koven, C., Jackson, R. B., Jones, C. D., Lara, M. J., Liang, J., McGuire, A. D., Parton, W. J., Peng, C., Randerson, J. T., Salazar, A., Sierra, C. A., Smith, M. J., Tian, H., Todd-Brown, K. E. O., Torn, M., van Groeningen, K. J., Wang, Y. P., West, O. T., Wei, Y., Wieder, W. R., Xia, J., Xia, X., Xu, $\mathrm{X}$., and Zhu, T.: Towards more realistic projections of soil carbon dynamics by Earth System Models, Global Biogeochem. Cy., 30, 40-56, doi:10.1002/2015GB005239, 2016.

Maire, V., Wright, I. J., Prentice, I. C., Batjes, N. H., Bhaskar, R., van Bodegom, P. M., Cornwell, W. K., Ellsworth, D., Niinemets, Ü., Ordonez, A., Reich, P. B., and Santiago, L. S.: Global effects of soil and climate on leaf photosynthetic traits and rates, Global Ecol. Biogeogr., 24, 706-715, doi:10.1111/geb.12296, 2015.

MEA: Ecosystems and Human Well-Being: Synthesis, Millennium Ecosystem Assessment Island Press, Washington, 2005.

North American Proficiency Testing (NAPT) Program: available at: http://www.naptprogram.org/ (last access: 27 April 2016), 2015.

Omuto, C., Nachtergaele, F., and Vargas Rojas, R.: State of the Art Report on Global and Regional Soil Information: Where are we? Where to go?, FAO, Italy, 69 pp., 2012.

Porter, C. H., Villalobos, C., Holzworth, D., Nelson, R., White, J. W., Athanasiadis, I. N., Zhang, M., Janssen, S., Knapen, R., Jones, J. W., Boote, K. J., Hargreaves, J., and Antle, J. M.: Data Interoperability Tools for Regional Integrated Assessments, in: Handbook of Climate Change and Agroecosystems, 147-171, 2015.

Ribeiro, E., Batjes, N. H., Leenaars, J. G. B., Van Oostrum, A. J. M., and Mendes de Jesus, J.: Towards the standardization and harmonization of world soil data: Procedures Manual ISRIC World Soil Information Service (WoSIS version 2.0) ISRIC - World Soil Information, Wageningen. Report 2015/03, 110 pp., 2015.
Ritchie, A.: OGC Soil Data Interoperability Experiment, Open Geospatial Consortium, 74 pp., 2016.

Shepherd, K. D. and Walsh, M. G.: Development of reflectance spectral libraries for characterization of soil properties, Soil Sci. Soc. Am. J., 66, 988-998, 2002.

Soil Survey Division Staff: Soil survey manual, Soil Conservation Service, U.S. Department of Agriculture, Washington, 503 pp., 1993.

Soil Survey Staff: Soil Survey Laboratory Information Manual (Ver. 2.0), National Soil Survey Center, Soil Survey Laboratory, USDA-NRCS, Lincoln (NE), Soil Survey Investigation Report No. 45, 506 pp., 2011.

UNEP: The benefits of soil carbon - managing soils for multiple, economic, societal and environmental benefits, in: UNEP Yearbook - Emerging issues in our global environment 2012, United Nations Environmental Programme, Nairobi, 19-33, 2012.

UNEP: UNEP Yearbook - Emerging issues in our global environment 2014, UNEP Yearbooks, United Nations Environmental Programme, Nairobi, 68 pp., 2014.

Van Engelen, V. W. P.: Standardizing soil data (e-SOTER regional pilot platform as EU contribition to a Global Soil Information System), International Innovation, June, 48-49, 2011.

van Engelen, V. W. P. and Dijkshoorn, J. A.: Global and National Soils and Terrain Digital Databases (SOTER) - Procedures manual (Ver. 2.0), IUSS, ISRIC and FAO, Wageningen. ISRIC Report 2013/04, 191 pp., 2013.

van Reeuwijk, L. P.: Guidelines for quality management in soil and plant laboratories, FAO, Rome, 143 pp., 1998.

van Reeuwijk, L. P.: Procedures for soil analysis, 6th Edn., ISRIC, Wageningen, Technical Paper 9, 81 pp., 2002.

Viscarra Rossel, R. A., Behrens, T., Ben-Dor, E., Brown, D. J., Demattê, J. A. M., Shepherd, K. D., Shi, Z., Stenberg, B., Stevens, A., Adamchuk, V., Aïchi, H., Barthès, B. G., Bartholomeus, H. M., Bayer, A. D., Bernoux, M., Böttcher, K., Brodský, L., Du, C. W., Chappell, A., Fouad, Y., Genot, V., Gomez, C., Grunwald, S., Gubler, A., Guerrero, C., Hedley, C. B., Knadel, M., Morrás, H. J. M., Nocita, M., Ramirez-Lopez, L., Roudier, P., Campos, E. M. R., Sanborn, P., Sellitto, V. M., Sudduth, K. A., Rawlins, B. G., Walter, C., Winowiecki, L. A., Hong, S. Y., and Ji, W.: A global spectral library to characterize the world's soil, Earth-Sci. Rev., 155, 198-230, doi:10.1016/j.earscirev.2016.01.012, 2016.

WEPAL: Wageningen Evaluating Programmes for Analytical Laboratories: available at: http://www.wepal.nl/website/about_wepal/ History.htm (last access: 28 May 2016), 2015.

Wilson, P. L.: Global harmonisation and exchange of soil data, SciDataCon 2016: Advancing the Frontiers of Data in Research, Denver (11-13 September 2016), Colorado, USA, 2016. 